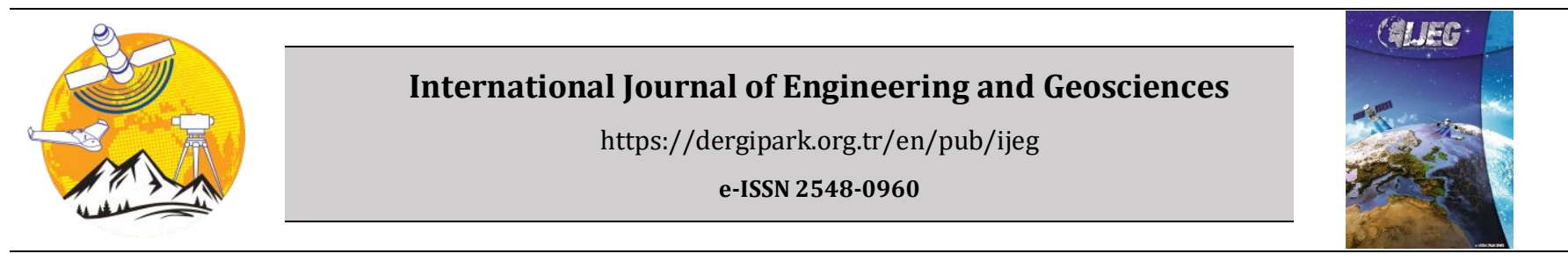

\title{
Agricultural land consolidation vs. land fragmentation in Russia
}

\author{
Alexander Sagaydak*1(D), Anna Sagaydak ${ }^{*}(\mathbb{D}$ \\ 1State University of Land Use Planning, Department of Agricultural Economics and Farm Management, Moscow, Russia
}

\author{
Keywords \\ Agricultural Land Consolidation \\ Agricultural Land Market \\ Project Analysis Principles Approach \\ Russia \\ Republic of Kalmykia
}

\begin{abstract}
The development of Agricultural Land Consolidation in Russia has always been unique, compared to other countries due to the state land policy, the vastness of the territory, and the variety of natural and soil conditions. Because of it, the internationally recognized and generally accepted approaches and models of it cannot always be accepted and applied. The consolidation of agricultural land in the country is developing sometimes spontaneously and is chaotic. At the federal level, there is an extended trend of the absorption of private land by parastatals. There is also an extended trend of decreasing the land use of coops and increasing the land use of jointstock companies and partnerships. The development of Agricultural Land Consolidation in Russia is primarily dependent on regional land policies. In Kalmykia, the unique trend continues to increase the number of private farms with an increase in their average size. In this regard, the super goal of the paper is to research how to apply Project Analysis Principles Approach to strengthen the development of Agricultural Land Consolidation in Russia. The specific objective of the paper is to research the role and importance of Agricultural Land Market tools to support the consolidation of agricultural lands.
\end{abstract}

\section{INTRODUCTION}

\subsection{Scope of work}

The development of land tenure in Russia has always been contradictory, spiral. It has always found its implementation in the struggle of two main trends: consolidation and fragmentation of agricultural land.

The consolidation and fragmentation of agricultural land at first glance act as opposite phenomena. Nevertheless, they are closely interrelated. Fragmentation of agricultural land objectively determines the need for further consolidation and vice versa.

Currently, the trend of consolidation of agricultural land is dominant. Agricultural Land Consolidation looks like complex phenomena, including technical, institutional, financial, economic, environmental, and social aspects, characterized by increasing scale and efficiency of agricultural production.

In this regard, the super goal of Agricultural Land Consolidation is to increase the efficiency of agricultural production to eliminate hunger, food shortages, poverty, and the gap in living conditions and incomes between urban and rural areas due to the rapidly growing world population and coronavirus pandemic.

The specific objectives of Agricultural Land Consolidation are an integration of small agricultural land parcels into large tracts of agricultural land; optimization of the size of agricultural land parcels, elimination of mosaic land ownership; increase the efficiency of use of agricultural machinery; the development production and social infrastructure in the countryside.

The main principles of Agricultural Land Consolidation are the following: voluntariness; openness; transparency; technical, institutional, financial, economic, environmental, and social feasibility; consideration of women, youth, and indigenous people as the main stakeholders; step by step implementation; taking into account local conditions; government and non-government organization support.

The other reason for the development of land consolidation in agriculture is that large agricultural 
producers are less sensitive to macroeconomic instability and the disparity of prices for agricultural and industrial commodities.

There are two primary forms of Agricultural Land Consolidation: compulsory and voluntary. One of the effective tools of voluntary Agricultural Land Consolidation is Agricultural Land Market.

The Agricultural Land Market is an Imperfect Competition Market because the number of sellers and buyers of agricultural land parcels doesn't fit each other.

Agricultural Land Market Transaction Information isn't clear and transparent. Agricultural Land Market Transactions are localized very much. The supply and demand for agricultural land allotments are 100\% inelastic.

In Agricultural Land Market available externalities: the state registration of the Agricultural Land Market Transactions; restrictions on the sale and purchase of agricultural land parcels; inappropriate agricultural land use: agricultural land and water pollution; illegal redistribution of agricultural land for non-agricultural and commercial purposes.

Transactions in the Agricultural Land Market are mainly carried out between neighbors who know each other well.

They look like the third party in the Agricultural Land Market and prevent the formation of equilibrium prices of agricultural land allotments.

\subsection{Empirical Literature}

The problem of land consolidation in agriculture and its geodetic support is reflected in numerous scientific studies, publications such as Backman (2010), Backman (2016), Becker and Halimi (2019), Biarel et al. (1992), Krigsholm et al. (2016), Konttinen (2016), Meijer and Emmens (2016), Satana et al. (2017), Sky (2015), Sulonen and Kotilainen (2016), Thomas (2006), Van den Noort (1987) and others, as well as, manuals, recommendations, and guidelines of international organizations (Voluntary Guidelines on the Responsible Governance of Tenure of Land, Fisheries and Forests in the Context of National Food Security (2012) FAO, Rome), Legal guide released by FAO in 2020 (Legal guide on land consolidation: Based on regulatory practices in Europe. FAO Legal Guide, No. 3. Rome, FAO (2020).

Backman (2010) and Backman (2016) studied and assessed the development and performance of Agricultural Land Consolidation based on cost-benefit analysis. He found and shaped out advantages of Agricultural Land Consolidation for landlords and society as a whole based on the Swedish experience. Backman found the main costs for a Land Consolidation project are an investigation of the composition and size of every owner's farm; individual talks with the landowners at "days of wishes"; elaboration of the design of the new consolidated properties; valuation of all properties; mediation and negotiation with all participating landowners; surveying of the new boundaries. The costs for a Land Consolidation project are influenced by: degree of fragmentation; the number of real properties/parcels; the number of landowners and their attitude; the size of the consolidation area; the length of all boundaries. Besides the measurable costs and disadvantages of Land Fragmentation for the proprietors, some factors cannot be measured e.g.: inefficient management in forestry; insecure ownership of many properties; inaccurate property registers and cadastral index maps; uncertain boundaries; ignorance among the proprietors regarding rights and location of boundaries causing disputes and conflicts; decision problems in co-owned properties.

Becker and Halimi (2019) treated Agricultural Land Consolidation as a multi-purpose instrument for the development of rural areas.

Biarel et al. (1992) studied the negative economic effect of farm fragmentation in African countries. They found that the existence of fragmented landholdings is an important feature in less developed agricultural systems. The costs of fragmentation include increased traveling time between fields (hence lower labor productivity and higher transport costs for inputs and outputs), negative externalities (such as reduced scope for irrigation and soil conserving investments as well as the loss of land for boundaries and access routes), and greater potential for disputes between neighbors. In light of these costs, numerous land reform policies have been aimed at enforcing, or at least subsidizing, the consolidation of holdings. These policies are premised on the assumption that fragmentation is necessarily inefficient and that agricultural production and social welfare can be increased through land consolidation.

Krigsholm et al. (2016), Konttinen (2016), Sulonen and Kotilainen (2016) analyzed the status, the efficiency of Land Consolidation on regional and agricultural development in Finland. They studied two land consolidation cases from Finland and evaluated their regional economic effects by using an input-output (IO) model. They found regional IO models provide multipliers that can be used to estimate the economywide effects that an initial change in economic activity, in this case, a land consolidation project, has on a regional economy. This study aimed to assess the regional economic impacts associated with the implementation of land consolidations. Particularly, they were focused on modeling: 1) total regional effects, 2) direct multiplier effects, and 3) indirect multiplier effects. They found and estimated the total regional impacts and direct and indirect multiplier effects. In short, direct multiplier effects were formed by increased consumption in households and sub-contractors that receive a salary that originates from the land consolidation project. Indirect multiplier effects were rippling down effects from subcontracts (i.e., subcontractor's subcontracts.

Konttinen (2016) evaluated the efficiency of Agricultural Land Consolidation in Finland. The author concluded that in the last two decades land consolidations in Finland were concentrated in agricultural areas. The main goal of the projects was a reduction of agricultural costs. Key figures when assessing the impact of a land consolidation project were parcel size and distance to the farmhouse.

Sulonen and Kotilainen (2016) investigated the determinants of Agricultural Land Consolidation for lessors in Finland. They discovered the lessors' concern that land consolidation causes additional and 
unnecessary costs for them. Experiences of costs, such as cost distribution and how well the rents of arable lands cover the costs of land consolidation are most negative among lessors. Nevertheless, the status of lessor may be improved in the future by focusing on informing and cost-sharing.

Meijer and Emmens (2016) studied, analyzed, and shaped out the financial arrangements for land consolidation. They examined the Agricultural Land Consolidation costs. They found two types of costs. The first is financial settlements. These are costs that are the result of the exchanges. For example, costs for increasing property area or improving soil quality. When a landowner gets more or less property due to land consolidation he will have to pay or has to be compensated. The second types of cost are procedure and implementation costs. These are the costs that will contribute to the landowners in the progress. The amount of these costs will depend on the project costs in total. The landowners who benefit more from the land consolidation pay more than those who do less. The benefits of allotment have to be evaluated. In the Netherlands, this is done by an independent commission.

Thomas (2006) tried to systematize Land Consolidation Approaches applied in Europe.

Satana et al. (2017) evaluated the Turkish Experience in Consolidation of Irrigated Land and assessed implications of Agricultural Land Consolidation Projects for Productivity and Efficiency for the agrarian sector of the national economy.

Sky (2015) examined the Agricultural Land experience in Norway based on the international experience of land consolidation. The author concluded although the organization and objectives of land consolidation vary from country to country, the actual process is surprisingly similar between countries. This means that a comparison between different nations is relevant. Norway is the only state where all land consolidation is dealt with by a special court. Land consolidation can have economic, social, legal, spatial, and environmental impacts, but a fundamental principle, not just in Norway, is that no party shall suffer loss as a result of land consolidation. This, therefore, constitutes an important prerequisite for the final solution. Almost all national land consolidation legislation admits the possibility of compelling unwilling parties to take part in the process.

Although there has been ample literature on Agricultural Land Consolidation available, we have focused on those studies that mostly evaluate the various Agricultural Land Consolidation Patterns' performance in the different countries of the world. From the above discussed empirical work, we can say that studies primarily related to Agricultural Land Consolidation Patterns are done in different countries of the world, for example, in Netherlands, Norway, Turkey, Sweden, and Finland. Nevertheless, the authors of the present study attempt to evaluate the performance of Agricultural Land Consolidation in Russia and Kalmykia, a federal subject of the Russian Federation.

However, because the development of land relations in Russia has always been unique in comparison with other countries in Europe and the world, due to the state policy, national and religious differences, the vastness of the territory, and the variety of climate, natural and soil conditions generally accepted approaches and models of Agricultural Land Consolidation cannot always be accepted and applied in the Russian Federation.

Due to the absence of theoretical studies in Russia on the matter, the consolidation of agricultural land in the country is developing sometimes spontaneously and chaotic.

In Russia, the problem of land consolidation in agriculture is also a subject of nationwide political discussion and closely related to developing the agricultural sector of the national economy: based on small private farms or large agricultural enterprises.

Some economists suppose that only the development of small private farms is necessary. In this regard, other economists think that only further development of agricultural holdings is necessary. Nevertheless, there is concern that the development of the agricultural holdings leads to the emergence of the so-called "latifundium", which should be treated as a system of land tenure based on sizeable private land ownership.

Also, satellite imagery and UAVs for implementing the Agricultural Land Consolidation Projects and the demarcation of the boundaries of the agricultural land allotments on the ground in rural areas remain controversial and poorly studied.

\section{METHOD}

\subsection{Methodology}

The methodology includes the study of theoretical foundations and practical recommendations for improving the consolidation of agricultural land in Russia based on the Project Analysis Principles Approach developed by the World Bank.

At the same time, using statistical methods and monographic surveys, trends in the development of Agricultural Land Consolidation at both the federal and regional levels were identified, which are: the concentration of land ownership by agricultural holdings and an increase in the average size of private farms while reducing their number.

In Kalmykia, a federal subject of Russia, the unique trend continues to increase the number of private farms with an increase in their average size.

In concept, this methodology is very close to the view expressed in the 2020 FAO Legal guide, according to which the consolidation of agricultural land is carried out by agricultural holdings and private farms (Legal guide on land consolidation: Based on regulatory practices in Europe. FAO Legal Guide, No. 3. Rome, FAO (2020).

Authors have declared that no competing interests exist related to this paper. The information used for this research paper is commonly and predominantly use statistical products in Russia and Kalmykia, a federal subject of the Russian Federation.

\subsection{Legal Framework}

The state cadastral valuation of agricultural land is carried out based on Federal Law No. 237-FZ of July 3, 2016 "On State Cadastral Valuation" and by the Order of 
the Ministry of Economic Development of Russia of May 12, 2017, No. 226 "On Approval of Methodological Guidelines on State Cadastral Valuation", which approved the main methodological approaches for conducting state cadastral valuation of real estate, including agricultural land.

\subsection{Institutional Framework}

In Kalmykia, there is a local office of the Rosreestr, which is responsible for the organization of a unified system of state cadastral registration of real estate, state registration of rights to immovable property, and real estate transactions and spatial data infrastructure.

The main task of the local branch of the Rosreestr is to maintain and provide information from the state real estate cadaster in Kalmykia.

Figure 1 displays Kalmyk cadastral region and cadastral districts of Kalmykia.

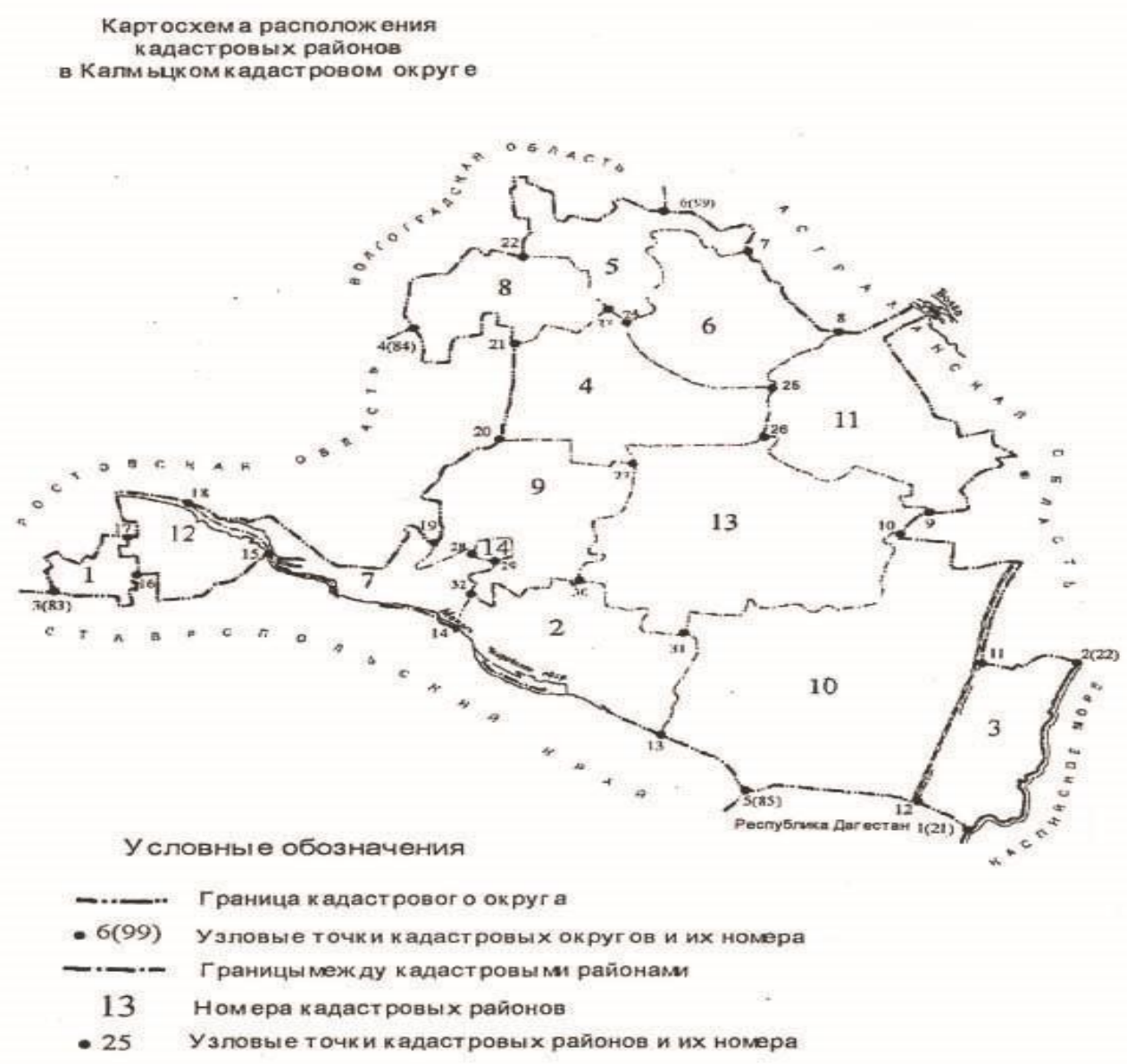

Figure 1. Kalmyk cadastral region and cadastral districts of Kalmykia (Source: The State (National) Report on the Status and Use of Lands in Russia in 2019, Rosreestr (2020))

\section{RESULTS}

\subsection{The development of Agricultural Land Consolidation in Russia}

In 2019, the total agricultural land area reduced in Russia by .4 M ha from 222.4 M ha to $222.0 \mathrm{M}$ ha, or by $.2 \%$, compared to 1990 (see Table 1 ).

In 2019, the cropland area decreased by $9.6 \mathrm{M}$ ha from $132.3 \mathrm{M}$ ha to $122.7 \mathrm{M}$ ha, or by $7.3 \%$, compared to 1990(The State (National) Report on the Status and Use of Lands in Russia in 2019, Rosreestr (2020).

In 2019, the area of pasture land increased by $5.1 \%$, and idle lands by 16.3 times, compared to 1990 (The State
(National) Report on the Status and Use of Lands in Russia in 2019, Rosreestr (2020) (see Table 1).

Table 1. Agricultural Land, Russia, 1990-2019, M ha

\begin{tabular}{llll}
\hline Item & 2019 & 1990 & $2019 / 1990, \%$ \\
\hline $\begin{array}{l}\text { Agricultural land } \\
\text { total, including: }\end{array}$ & 222.0 & 222.4 & 99.8 \\
Cropland & 122.7 & 132.3 & 92.7 \\
Pasture & 92.4 & 87.9 & 105.1 \\
Idle land & 4.9 & .3 & 16.3 times \\
\hline
\end{tabular}

Source: The State (National) Report on the Status and Use of Lands in Russia in 2019, Rosreestr (2020) 
In 2019, the state and municipal-owned land amounted to $1,579.5 \mathrm{M}$ ha, or $92.2 \%$, private land $-111.1 \mathrm{M}$ ha, or $6.5 \%$, and land owned by legal entities $-21.9 \mathrm{M}$ ha, or $1.3 \%$, of total Russia's territory.

The state and municipal-owned land in Russia increased by $.1 \mathrm{M}$ ha from $1,579.4 \mathrm{M}$ ha to $1,579.5 \mathrm{M}$ ha in 2019 , compared to 2018 , or by less than .1\%.

The share of the state and municipal-owned land in the total land of Russia was not changed in 2019, compared to 2018.

The private land area decreased by $1.0 \mathrm{M}$ ha in 2019 , compared to 2018 from $112.1 \mathrm{M}$ ha to $111.1 \mathrm{M}$ ha or by .9 $\%$.

In 2019, the share of private land in the total land of Russia decreased by .1 pp. from $6.6 \%$ to $6.5 \%$, compared to 2018.

At the same time, the area of land owned by legal entities increased by $.9 \mathrm{M}$ ha in 2019 compared to 2018 from $21.0 \mathrm{M}$ ha to $21.9 \mathrm{M}$ ha, or by $4.3 \%$.

The share of land owned by legal entities in the total land of Russia increased in 2019, compared to 2018 by .1 pp. from $1.2 \%$ to $1.3 \%$.

The state and municipal-owned agricultural land amounted to $254.1 \mathrm{M}$, ha, or $66.6 \%$, private land - $106.6 \mathrm{M}$ ha, or $27.9 \%$, and land owned by legal entities $-20.9 \mathrm{M}$ ha, or $5.5 \%$, of total Russia's agricultural land in 2019.

Thus, in 2019, the private agricultural land area decreased by $1.0 \mathrm{M}$ ha from $107.6 \mathrm{M}$ ha to $106.6 \mathrm{M}$ ha, or by $1.0 \%$, compared to 2018 .

In 2019 , the area of agricultural land owned by legal entities increased by $.9 \mathrm{M}$ ha from $20.0 \mathrm{M}$ ha to $20.9 \mathrm{M}$ ha, or by $4.5 \%$, compared to 2018 .

Moreover, in 2019, the state and municipal-owned agricultural land area decreased by $.7 \mathrm{M}$ ha from $254.8 \mathrm{M}$ ha to $254.1 \mathrm{M}$ ha, or by $.3 \%$, compared to 2018 .

In 2019, the share of the state and municipal-owned agricultural land was not changed in the total agricultural land of Russia, compared to 2018.

In 2019 , the share of agricultural land owned by legal entities increased by $.3 \mathrm{pp}$ from $5.2 \%$ to $5.5 \%$ in the total agricultural land of Russia, compared to 2018.

In 2019 , the share of the privately-owned agricultural land decreased by $.3 \mathrm{pp}$ from $28.2 \%$ to $27.9 \%$ in the total agricultural land of Russia, compared to 2018.

Thus, there is an extended trend of the absorption of private land by legal entities at the federal level.

In particular, this is also evident in the fact that a dominant role in agricultural land use in Russia has played joint-stock companies and production coops.

In 2019, the share of joint-stock companies and partnerships in the total area of agricultural land use of parastatals increased by .6 pp. from $54.0 \%$ to $54.6 \%$ in Russia, compared to 2018 (The State (National) Report on the Status and Use of Lands in Russia in 2019, Rosreestr (2020) (see Table 2).

In 2019, the share of joint-stock companies and partnerships in cropland of parastatals increased by .7 pp. from $59.4 \%$ to $60.1 \%$ in Russia, compared to 2018 .

At the same time, in 2019, the share of production coops in the total area of agricultural land use of parastatals decreased by .6 pp. from $35.1 \%$ to $34.5 \%$ in Russia, compared to 2018.
Table 2. Parastatal's Land Use, Russia, 2019, K ha

\begin{tabular}{ccc}
\hline Item & Total & Cropland \\
\hline Joint-Stock Companies & 62,503 & $44,430.2$ \\
and Partnerships & $34,428.8$ & $22,395.2$ \\
Production Coops & 5,448 & $2,413.5$ \\
State and Municipal & $1,627.9$ & $1,242.7$ \\
Enterprises & 868.2 & 527.0 \\
Research Institutions & $4,367.4$ & $2,800.2$ \\
Subsidiary Farms & 15.9 & .4 \\
Other & 95.2 & 66.1 \\
Tribal Land & $114,354.4$ & $73,875.3$ \\
Cossack Society Land &
\end{tabular}

Source: The State (National) Report on the Status and Use of Lands in Russia in 2019, Rosreestr (2020)

In 2019, the share of production coops in cropland of parastatals decreased by .7 pp. from $31.0 \%$ to $30.3 \%$ in Russia, compared to 2018(The State (National) Report on the Status and Use of Lands in Russia in 2019, Rosreestr (2020).

Thus, there is an extended trend of decreasing land use of production coops and increasing land use of jointstock companies and partnerships, indicating further development of the Agricultural Land Consolidation by large and medium agricultural enterprises.

The average size of the ten most extensive agricultural holdings amounted to $608.2 \mathrm{~K}$ ha in 2020 . In 2020 , it increased by $18.6 \%$, compared to 2018. In 2020, it increased by $5.8 \%$, compared to 2019. It varied from $380 \mathrm{~K}$ ha to $1,047 \mathrm{~K}$ ha in 2020 (see Table 3) (Rating of the largest owners of agricultural land in Russia in May 2020, 2020).

Table 3. Agricultural Holdings Land Ownership, Russia, 2020, K ha

\begin{tabular}{ccc}
\hline Item & Agricultural land & $\%$ \\
\hline Miratorg & 1,047 & 17.2 \\
Prodimex\&Agrokultura & 865 & 14.2 \\
Agrokomplex & 653 & 10.8 \\
Rusagro & 643 & 10.6 \\
EcoNiva-APK & 599 & 9.9 \\
Step+RZ Agro & 542 & 8.9 \\
BIO-TON & 452 & 7.4 \\
Volga -Don Agroinvest & 451 & 7.4 \\
Avangard-Agro & 450 & 7.4 \\
Vasilina & 380 & 6.2 \\
\hline Total & 6,082 & 100.0
\end{tabular}

Source: Rating of the largest owners of agricultural land in Russia in May 2020(2020)

Private farms play an important role in Russian agricultural private land use (see Table 4).

In 2019, the share of private farms in the total area of the private agricultural land use increased by $.2 \mathrm{pp}$ from $32.0 \%$ to $32.2 \%$, compared to 2018 due to land consolidation (The State (National) Report on the Status and Use of Lands in Russia in 2019, Rosreestr (2020).

In 2019 , the share of private farms in the total private area of the cropland use increased by .1 pp from $40.2 \%$ to $40.3 \%$, compared to 2018 due to land consolidation 
(The State (National) Report on the Status and Use of Lands in Russia in 2019, Rosreestr (2020).

Table 4. Private Land Use, Russia, 2019, K ha

\begin{tabular}{ccc}
\hline Item & Total & Cropland \\
\hline Private Farms & $25,807.1$ & $17,472.3$ \\
Individual Entrepreneurs & $3,403.4$ & $2,499.6$ \\
Personal Subsidiary Farms & $7,467.4$ & $5,129.3$ \\
of Citizens & 53.5 & 10.6 \\
Service Land & $1,116.9$ & 53.1 \\
Horticulture Farms & 272.7 & 270.1 \\
Vegetable Growing Farms & 100.4 & 76.7 \\
Outreach Dacha Farms & 595.5 & 495.6 \\
Housing Parcels & 388.0 & 57.9 \\
Livestock Farms & $15,197.8$ & $1,168.3$ \\
Grazing Farms & $12,655.7$ & $9,283.8$ \\
Land Parcels Owners & $12,211.6$ & $6,594.8$ \\
Land Shares Owners & $79,270.0$ & $43,112.1$ \\
\hline Total &
\end{tabular}

Source: The State (National) Report on the Status and Use of Lands in Russia in 2019, Rosreestr (2020)

In 2019 , the number of private farms decreased by 7.5 \%, compared to 1995 in Russia due to the severe macroeconomic environment, the disparity of prices for agricultural and industrial commodities, lack of developed infrastructure.

However, the average size of agricultural land occupied by the private farm has been increased due to land consolidation.

It was estimated at 76.6 ha in 2019 . Thus, in 2019 , it increased by $78.6 \%$, compared to 1995 (The State (National) Report on the Status and Use of Lands in Russia in 2019, Rosreestr (2020) (see Table 5).

Table 5. Russia's Private Farming, 1995-2019

\begin{tabular}{cccc}
\hline Item & 2019 & 1995 & $2019 /$ \\
& & & $1995, \%$ \\
\hline Number of farms, K & 258.3 & 279.1 & 92.5 \\
Total land area, K ha & $19,795.5$ & $11,982.1$ & 165.2 \\
Average land size, ha & 76.6 & 42.9 & 178.6 \\
\hline
\end{tabular}

Source: The State (National) Report on the Status and Use of Lands in Russia in 2019, Rosreestr (2020)

The development of Agricultural Land Consolidation in Russia is mostly dependent on regional land policies.

Kalmykia is located in the South-East of the European part of Russia. Kalmykia agricultural land amounted to $6,937.3 \mathrm{~K}$ ha, or $92.8 \%$, of the total regional land in 2019(see Table 6).

Here we can observe a unique trend of increasing area of agricultural land in 2010-2019.

In 2019, the total area of agricultural land increased by $52.1 \mathrm{~K}$ ha, or $.8 \%$, from $6,885.2 \mathrm{~K}$ ha to $6,937.3 \mathrm{~K}$ ha, compared to 2010(Regional Report on the Status and Use of Lands in Kalmykia in 2019, Kalmykiareestr (2020).

The main role in Kalmykia agricultural land use plays joint-stock companies and partnerships and production coops (see Table 7). In general, parastatals occupied $1,755.8 \mathrm{~K}$ ha or $25.3 \%$ of the total agricultural land area of the region in 2019.
Table 6. Kalmykia's Land, 2010-2019, K ha

\begin{tabular}{cccc}
\hline Land & 2019 & 2010 & $2019 / 2010, \%$ \\
\hline Agricultural & $6,937.3$ & $6,885.2$ & 100.8 \\
Urban & 62.4 & 62.4 & 100.0 \\
Industrial & 15.7 & 15.0 & 104.7 \\
Special & 121.6 & 121.6 & 100.0 \\
Forest & 60.2 & 60.2 & 100.0 \\
Water & 60.1 & 59.1 & 101.4 \\
Reserve & 215.8 & 269.6 & 80.0 \\
\hline Total & $7,473.1$ & $7,473.1$ & 100.0 \\
\hline
\end{tabular}

Source: Regional Report on the Status and Use of Lands in Kalmykia in 2019, Kalmykiareestr (2020)

In 2019, the area of land use of parastatals decreased by $279.3 \mathrm{~K}$ ha, or $13.7 \%$, from $2,035.1$ to $1,755.8 \mathrm{~K}$ ha, compared to 2015 .

In 2019, the share of the above-mentioned land use in the total agricultural land area of the region decreased by 4.1 pp from $29.4 \%$ to $25.3 \%$, compared to 2015 (Regional Report on the Status and Use of Lands in Kalmykia in 2019, Kalmykiareestr (2020).

Table 7. Parastatal's Land Use, Kalmykia, 2019, K ha

\begin{tabular}{lll}
\hline Item & Area & Land leasing \\
\hline Joint-Stock Companies & 690.5 & 22.7 \\
and Partnerships & 767.3 & 15.7 \\
Production Coops & \\
State and Municipal & 134.0 & - \\
Enterprises & 30.5 & - \\
Research Institutions & 133.3 & - \\
Others & $1,755.8$ & 38.4 \\
\hline Total &
\end{tabular}

Source: Regional Report on the Status and Use of Lands in Kalmykia in 2019, Kalmykiareestr (2020)

Joint-stock companies and partnerships occupied $690.5 \mathrm{~K}$ ha or $9.9 \%$ of the total agricultural land used in the region in 2019.

In 2019 , the area of agricultural land used decreased by $43.3 \mathrm{~K}$ ha, or $5.9 \%$, from 733.8 to $690.5 \mathrm{~K}$ ha, compared to 2015.

In 2019, the land use of joint-stock companies and partnerships increased from $647.1 \mathrm{~K}$ ha to $690.5 \mathrm{~K}$ ha, or by $43.4 \mathrm{~K}$ ha, or by $6.7 \%$, compared to 2018 .

The share of land use of joint-stock companies and partnerships in the total area of agricultural land in the region increased by .6 pp from $9.3 \%$ to $9.9 \%$ over this period.

In2019, the share of the above-mentioned land use in the total agricultural land area of the region decreased by .7 pp from $10.6 \%$ to $9.9 \%$ compared to 2015 .

They have also used most of the agricultural land shares $(94.1 \%)$ rented by parastatals in Kalmykia.

In 2019, the percentage of land shares rented by jointstock companies and partnerships increased by $44.0 \mathrm{pp}$ from $49.7 \%$ to $94.1 \%$, compared to 2018 due to a sharp decrease in the share of production coops.

The share of these businesses in the state and municipal-owned lands amounted to $90.0 \%$ of their total area in 2019.

In 2019, the share of the above-mentioned land use in the total land use of joint-stock companies and partnerships decreased by 6.0 pp from $96.0 \%$ to $90.0 \%$, compared to 2015. 
In 2019, compared to 2018, the share of state and municipal land used by joint-stock companies and partnerships decreased by $3.1 \mathrm{pp}$ from $93.1 \%$ to $90.0 \%$.

In general, joint-stock companies and partnerships occupied $39.3 \%$ of the total land area owned by parastatals in 2019.

Thus, in 2019, their share in the land use of parastatals in Kalmykia increased by 3.3 pp from $36.0 \%$ to $39.3 \%$, compared to 2018 .

Production coops occupied $767.3 \mathrm{~K}$ ha, or $11.1 \%$, of the total agricultural land area of the region in 2019.

In 2019, the production coops area decreased by $212.2 \mathrm{~K}$ ha, or $27.6 \%$, from 979.5 to $767.3 \mathrm{~K}$ ha, compared to 2015.

In 2019, the land use of production coops decreased from $834.8 \mathrm{~K}$ ha to $767.3 \mathrm{~K}$ ha by $67.5 \mathrm{~K}$ ha, or $8.1 \%$, compared to 2018.

In 2019, the share of the above-mentioned land use in the total agricultural land area of the region decreased by $1.0 \mathrm{pp}$ from $12.1 \%$ to $11.1 \%$, compared to 2015 .

In 2019, the share of the above-mentioned land use in the total agricultural land area of the region decreased by $.9 \mathrm{pp}$ from $11.1 \%$ to $10.2 \%$, compared to 2018 .

The share of the state and municipal-owned lands used by production coops amounted to $97.0 \%$ of their total area in 2019.

In 2019, the share of land use of production coops in the total land use of production coops decreased by 2.3 pp from $99.3 \%$ to $97.0 \%$ compared to 2015 .

In 2019, the share of production coops in the land use structure in the region increased by $1.6 \mathrm{pp}$ from $95.4 \%$ to $97.0 \%$ compared to 2018 .

In general, production coops occupied $43.5 \%$ of the total land area owned by parastatals in 2019.

In 2019, the share of production coops in the land used structure of parastatals decreased from $48.1 \%$ to $43.5 \%$, or by $4.6 \mathrm{pp}$, compared to 2015 .

In 2019, the share of coops in the structure of land used of parastatals decreased by $3.0 \mathrm{pp}$ from $46.5 \%$ to 43.5\%, compared to 2018.

An important role in Kalmykia private agricultural land tenure plays land shares.

The total land share area amounted to $881.0 \mathrm{~K}$ ha, or $59.8 \%$, of the private land area.

In 2019 , the area of land shares decreased by $221.8 \mathrm{~K}$ ha, or $20.1 \%$, from $1,102.8$ to $881.0 \mathrm{~K}$ ha, compared to 2015. In 2019, the share of the above-mentioned land in the total private land area of the region decreased by 7.3 pp from $26.3 \%$ to $19.519 .0 \%$, compared to 2015 . In

2019 , land shares in the region decreased by $9.1 \mathrm{~K}$ ha from $890.1 \mathrm{~K}$ ha to $881.0 \mathrm{~K}$ ha, or by $1.0 \%$, compared to 2018.

In 2019, the share of the above-mentioned land in the total private land area of the region decreased by $.5 \mathrm{pp}$ from $19.5 \%$ to $19.0 \%$, compared to 2018(Regional Report on the Status and Use of Lands in Kalmykia in 2019, Kalmykiareestr (2020) (see Table 8).

In Kalmykia, we can observe a unique and extended trend: the increase in the number of private farms and the increase in their average size (see Table 9).
Table 8. Private Land Use, Kalmykia, 2019, K ha

\begin{tabular}{lll}
\hline Item & $\begin{array}{l}\text { Total land } \\
\text { area }\end{array}$ & $\begin{array}{l}\text { Private } \\
\text { ownership }\end{array}$ \\
\hline $\begin{array}{l}\text { Private Farms } \\
\text { Individual Entrepreneurs }\end{array}$ & $\begin{array}{l}3,212.9 \\
\text { Personal Subsidiary Farms }\end{array}$ & 61.5 \\
of Citizens & 7.2 & 1.7 \\
Horticulture Farms & 1.3 & 2.1 \\
Vegetable Growing Farms & - & .9 \\
Housing Parcels & 5.5 & - \\
Livestock Farms & 1.3 & 3.9 \\
Land Parcels Owners & 521.7 & .7 \\
Land Share Owners & 881.0 & 521.7 \\
\hline Total & $4,635.5$ & 881.0 \\
\hline
\end{tabular}

Source: Regional Report on the Status and Use of Lands in Kalmykia in 2019, Kalmykiareestr (2020)

Table 9. Kalmykia's Private Farming, 1992-2019

\begin{tabular}{|c|c|c|c|}
\hline Item & 2019 & 1992 & $\begin{array}{l}\text { 2019/1992, } \\
\text { times }\end{array}$ \\
\hline Number of farms & 3,042 & 292 & 10.4 \\
\hline Total land area, $\mathrm{K}$ ha & $3,212.9$ & 168 & 19.1 \\
\hline Average land size, ha & 1,056 & 575 & 1.8 \\
\hline
\end{tabular}

Source: Regional Report on the Status and Use of Lands in Kalmykia in 2019, Kalmykiareestr(2020)

In 2019, the number of private farms in Kalmykia increased, compared to 1992 by 10.4 times. In 2019, the land area occupied by private farms in the region increased, compared to 1992 by 19.1 times. The average size of the private farm amounted to 1,056 ha in Kalmykia in 2019. It increased in 2019, compared to 1992 by 1.8 times, due to land consolidation based on renting and buying of agricultural land shares. It is significantly different from the average for Russia, where a reduction in their number accompanies an increase in the area above-mentioned farms.

\subsection{Agricultural Land Market Tools}

The Agricultural Land Market in Kalmykia has been steadily developed despite the increase in the cadastral value of the land.

To encourage land consolidation, it is necessary to develop the Agricultural Land Market based on land auctions. In turn, the market price of land is the basis for Agricultural Land Taxation and Agricultural Land Mortgage transactions.

The Starting Agricultural Land Market Auction Price Model (SALAPM) was developed (Sagaydak and Sagaydak, 2016) and Agricultural Land Values and Taxation Rates were determined for 2021 (see Table 10) based on that concept.

Land tax is calculated as . $3 \%$ of the starting auction price of agricultural land. In theory, the contract land rent rate can't be less than land tax rates. Otherwise, the landowner will not be interested to give land on lease.

Therefore, it is necessary to provide at least the average level of profitability for the landowner that can be taken as $40 \%$ compared to the rate of land tax. You can see the above mentioned-market prices of agricultural land calculated for the local municipalities on the map of Kalmykia designed by Yandex (see Figure 2). 
Table 10. Agricultural Land Values and Taxation, Kalmykia, Rub/ha (draft)

\begin{tabular}{lllll}
\hline Municipalities & $\begin{array}{l}\text { Cadast } \\
\text { ral } \\
\text { Value }\end{array}$ & $\begin{array}{l}\text { Starting } \\
\text { Auction } \\
\text { Price }\end{array}$ & $\begin{array}{l}\text { Mortga } \\
\text { ge } \\
\text { Value }\end{array}$ & $\begin{array}{l}\text { Land } \\
\text { Tax }\end{array}$ \\
\hline Gorodovikovskoe & 84,580 & 14,912 & 10,438 & 44.74 \\
Iki-Burulskoe & 10,760 & 1,904 & 1,332 & 5.71 \\
Ketchenerovskoe & 11,800 & 2,080 & 1,456 & 6.24 \\
Laganskoe & 2,800 & 494 & 345 & 1.48 \\
Maloderbetovskoe & 12,430 & 2,186 & 1,530 & 6.56 \\
Oktyabr'skoe & 4,200 & 740 & 518 & 2.22 \\
Priyoutnenskoe & 19,800 & 3,490 & 2,443 & 10.47 \\
Sarpinskoe & 13,570 & 2,397 & 1,678 & 7.19 \\
Tselinnoe & 10,980 & 1,939 & 1,357 & 5.82 \\
Chernozemelskoe & 2,900 & 511 & 358 & 1.53 \\
Youstinskoe & 3,150 & 546 & 382 & 1.64 \\
Yashaltinskoe & 39,050 & 6,874 & 4,812 & 20.62 \\
Yashkul'skoe & 2,440 & 2,115 & 1,481 & 6.34 \\
\hline Average & 15,760 & 2,961 & 2,073 & 8.88 \\
\hline
\end{tabular}

However, when determining the starting auction price of agricultural land, such important price-forming factors as demand and supply for specific land parcels in the agricultural sector of the national economy in Russia are not taken into account.

At the same time, the starting auction price of land in agriculture acts as a basic, relatively certain component of the market price of agricultural land, while the influence of supply and demand on the price of land parcels introduces uncertainty in the pricing process for land.

Accounting for the above price-forming factors can be carried out based on determining the market values of "put" and "call" options for agricultural land parcels.

The put option acts as a contract between the seller and the buyer of the derivative. The owner has the opportunity to sell an agricultural land parcel at a preagreed strike price during the term of the contract.

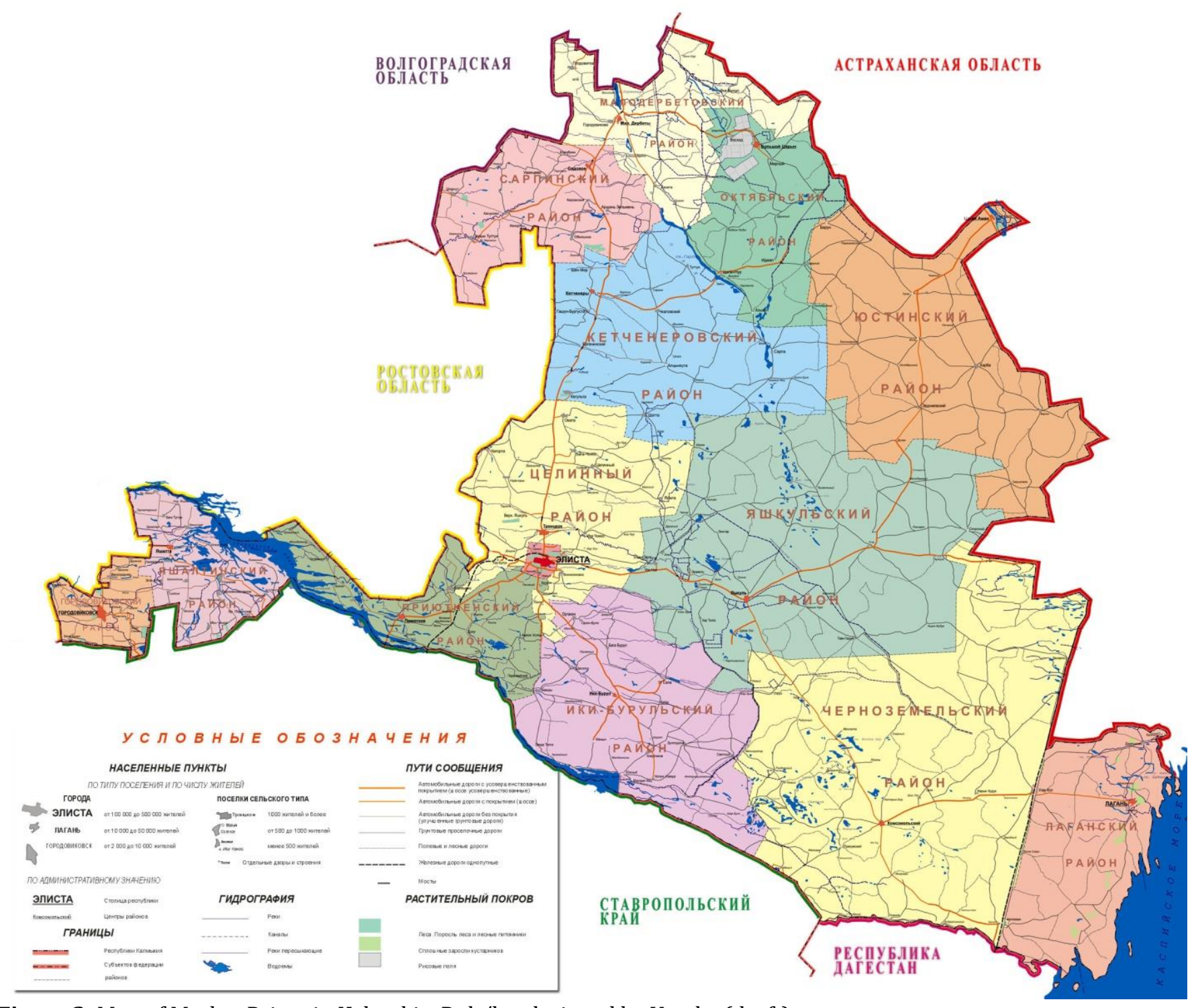

Figure 2. Map of Market Prices in Kalmykia, Rub/ha, designed by Yandex(draft)

The value of this option determines by the premium that the buyer of the derivative pays to its seller and determine by the yield of this financial instrument, depending on changes in the market price of the land parcel under the influence of supply and demand factors for agricultural land.

If the market price of the agricultural land parcel exceeds the fixed price of the derivative, the option holder will not sell it. 
If the agricultural land parcel market price is lower than the exercise price of the option, then the owner of the derivative sells it.

In this case, the profit of the option holder will be equal to the spread between the fixed strike price of the derivative and the market price of the land, minus the premium paid to them when purchasing the option.

Therefore, the market price of an agricultural land parcel will be equal to:

$$
\mathrm{Rm}_{\mathrm{m}}=\mathrm{P}_{\mathrm{s}}+\mathrm{C}_{\text {put }}
$$

where

$\mathrm{R}_{\mathrm{m}^{\prime}}-$ market price of an agricultural land parcel, Rub;

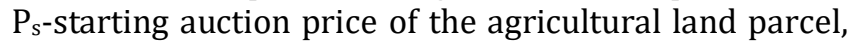
Rub; $\mathrm{C}_{\text {put }}$ - value (premium) of the "put" option, Rub.

The call option also acts as a contract between the buyer and the seller of the derivative, which allows the buyer of the option to buy land in the future at a fixed strike price for a period specified in the contract.

The seller of the option obliges to sell his land parcel if the buyer-owner of the derivative wants to purchase land since he was already paid a premium after the contract.

At the same time, the buyer-owner of the "call" option makes a profit if the land price tends to increase. As a result, the market price of an agricultural land parcel will be equal to:

$$
\mathrm{R}_{\mathrm{m}} "=\mathrm{P}_{\mathrm{s}}+\mathrm{C}_{\text {call }}
$$

where

$\mathrm{R}_{\mathrm{m}}$ " - market price of an agricultural land parcel, Rub; $\mathrm{P}_{\mathrm{s}}$-starting auction price of the agricultural land parcel, Rub; Ccall- the cost (premium) of the "call" option, Rub.

However, the ratio of the option value of "put" and "call" the land in agriculture reflects their parity, equivalence, as prices of option "put" in the short term and call option in the long term equal to contract value "forward" for sale agricultural land with the same fixed strike price.

Ensuring the principle of equivalence of the values of the above-mentioned derivatives is implemented based on fulfilling the condition of the need for the absence of arbitration transactions with them in spatial and temporal aspects. This means that if the value of a land parcel of agricultural land is higher than the fixed exercise price of the option, then a contract for the land is concluded based on the "call" option, and if it is lowerthe "put" option.

In each particular case, the actual price of an agricultural land parcel may deviate from the fixed prices of their execution established in the contracts of "put" and "call" options.

The development of the process of consolidation of agricultural land leads to a quantitative increase in the amount of land rent and, accordingly, to an increase in the market value of land parcels in the agricultural sector of the national economy in Russia.

Experience shows that the market value (premium) of "call" options in terms of growth of their value is on average about $3 \%$ of the offer price at land auctions.
Therefore, the market price of agricultural land can be represented as the sum of the starting auction price of it and the value (premium) of the "call" option for land parcels. This approach to determining the market value of agricultural land was tested on the materials of Kalmykia (see Table 11).

Table 11. Agricultural Land Market Prices, Kalmykia, Rub/ha (draft)

\begin{tabular}{llll}
\hline Municipalities & $\begin{array}{l}\text { Starting } \\
\text { Auction } \\
\text { Price }\end{array}$ & $\begin{array}{l}\text { Call } \\
\text { Premium }\end{array}$ & $\begin{array}{l}\text { Land } \\
\text { Market } \\
\text { Price }\end{array}$ \\
\hline Gorodovikovskoe & 14,912 & 447 & 15,359 \\
Iki-Burulskoe & 1,904 & 57 & 1,961 \\
Ketchenerovskoe & 2,080 & 62 & 2,142 \\
Laganskoe & 494 & 15 & 509 \\
Maloderbetovskoe & 2,186 & 66 & 2,252 \\
Oktyabr'skoe & 740 & 22 & 762 \\
Priyoutnenskoe & 3,490 & 105 & 3,595 \\
Sarpinskoe & 2,397 & 72 & 2,469 \\
Tselinnoe & 1,939 & 58 & 1,997 \\
Chernozemelskoe & 511 & 15 & 526 \\
Youstinskoe & 546 & 16 & 562 \\
Yashaltinskoe & 6,874 & 206 & 7,080 \\
Yashkul'skoe & 2,115 & 63 & 2,178 \\
\hline Average & 2,961 & 89 & 3,050 \\
\hline
\end{tabular}

According to Table 11, the market price of agricultural land parcels can be interpreted as the auction price of land, adjusted for the interaction of supply and demand factors due to the situation on the land market.

This methodology implies further development of the Agricultural Land Market, auction trade in agricultural land parcels, and financial and credit relations, both in the agricultural sector and in the national economy of Russia as a whole.

It's also important to implement a Logical Framework Methodology for designing Agricultural Land Consolidation Projects.

As we mentioned before, the super goal of Agricultural Land Consolidation Projects is to implement and develop Agricultural Land Consolidation to increase the efficiency of agricultural production to eliminate hunger and food shortages as well as poverty due to the rapidly growing world population and coronavirus pandemic.

Thus, Agricultural Land Consolidation looks like a complex social and economic process, including technical, institutional, financial, economic, environmental, and social aspects, highlighting advanced and internationally recognized the World Bank's Agricultural Project Analysis Methodology.

The aim of Technical Analysis of Agricultural Land Consolidation is the implementation of land use planning activities focused on the removal of mosaic agricultural land ownership, optimization of the configuration and size of agricultural land parcels and the development of the highway network, social and production facilities in the countryside to increase agricultural production and reduce of its costs.

The goal of Institutional Analysis of Agricultural Land Consolidation Projects describes the selection of institutions or beneficiaries interested in implementing 
them based on indicators of financial and economic efficiency. The stakeholder may be any legal entity, for instance, private farms, agricultural holdings.

The purpose of the Financial Analysis of Agricultural Land Consolidation Projects is to determine their financial efficiency for any organization directly involved and responsible in their implementation based on costbenefit analysis.

It should be noted that with increasing the size of agricultural land parcels the financial efficiency of agricultural production is increasing due to the relative reduction of transaction costs per unit of agricultural land area used.

The maximum efficiency of farming is reached when the level of transaction costs per unit of agricultural land used is reduced to a minimum level.

However, following increasing the size of agricultural land allotments used leads to decreasing financial efficiency of farming due to the increase in transaction costs per unit of agricultural land area used (Figure 3).

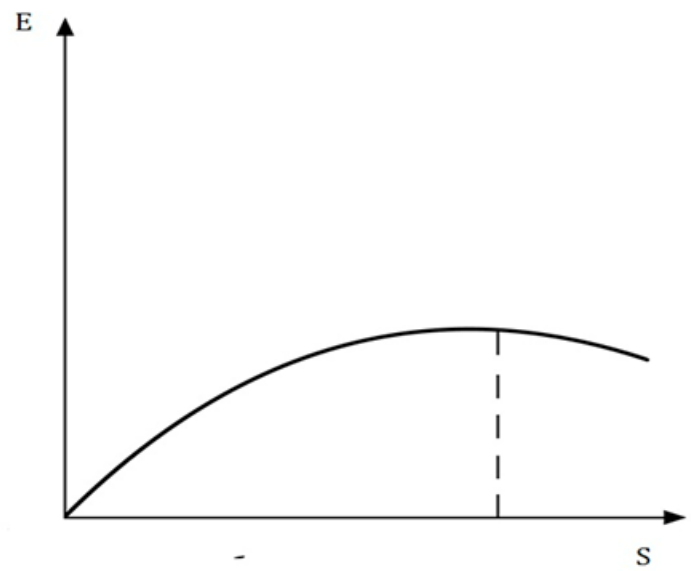

Figure 3. Dependence of the efficiency of the Agricultural Land Consolidation Project (E) on its scale(S)

In this regard, the main problem is analyzing and evaluating the financial efficiency of Agricultural Land Consolidation Projects based on cost-benefit analysis (Backman, 2010), (Backman, 2016).

The most important condition for applying costbenefit analysis for the evaluation of financial efficiency of Agricultural Land Consolidation Projects is to ensure adequate assessment and comparability of financial indicators of costs, benefits, and efficiency criteria based on an international financial reporting system, for example, US GAAP. It could create additional incentives to attract outside investors to come and input their capital in agriculture.

In that sense, the allocation of capital as investments in agriculture is based on Agricultural Land Consolidation.

The Economic Analysis of Agricultural Land Consolidation Projects aims to determine their economic efficiency for society as a whole and regions based on analysis of economic assessment costs and benefits via "shadow" price.

The Environment Analysis of Agricultural Land Consolidation Projects focuses on assessing their impact on the environment based on direct and indirect marketing valuation methods, for example, "shadow" projects.

The Social Analysis of Agricultural Land Consolidation Projects aims to assess their impact on the social, cultural, and demographic characteristics, the social organization, cultural acceptability, and different groups of population such as women, indigenous people, and youth.

The Agricultural Land Consolidation Project's Life Circle consists of Creative Design Phase and the Implementation Phase (Figure 4).

In turn, the Creative Design Phase consists of Identification, Feasibility Study, Preparation, Detailed Design, and Appraisal Stages. The Implementation Phase consists of Negotiation, Loan Approval, Implementation, Supervision, and Completion Stages.

The goals and objectives of the Agricultural Land Consolidation Project are determined at the Identification Stage.

Technical Analysis, Institutional Analysis, Financial Analysis, Economic Analysis, Environmental Analysis, and Social Analysis of the Agricultural Land Consolidation Projects are carried out at the Prefeasibility Study Stage and Feasibility Study Stage.

A business plan for the Agricultural Land Consolidation Project is developed at the Preparation Stage.

Clarification of the business plan for the Agricultural Land Consolidation Project due to changes in the macroeconomic situation is carried out at the Detailed Design Stage.

The external expertise of the Agricultural Land Consolidation Project is carried out at the Appraisal Stage.

Further, the business plan of the Agricultural Land Consolidation Project is submitted to the bank to resolve the issue of allocation of loans for its financing.

To this end, the owners and beneficiaries of the Agricultural Land Consolidation Project and the bank negotiate a loan to finance it.

The signing of the loan agreement is carried out at the Negotiation and Loan Approval Stages to finance the Agricultural Land Consolidation Project.

The Agricultural Land Consolidation Project starts at the Direct Implementation Stage. Geodetic and land use planning works focused on the consolidation of small parcels into larger agricultural land allotments are carried out here.

Monitoring of the progress of the Agricultural Land Consolidation Project in terms of cost and implementation time is carried out at the Supervision Stage using the PERT (Project Evaluation and Report Technique) and GERT (Graphical Evaluation and Report Technique) Methodologies.

As a result of the Agricultural Land Consolidation Project, agricultural land allotments should be formed, allowing for farming and the use of modern agricultural machinery and technologies effectively.

At the Completion Stage of the Agricultural Land Consolidation Project, a retrospective analysis of its implementation is also carried out, which allows identifying all the pros and cons of its implementation. 
Training capabilities and public information programs should be included in the Agricultural Land Consolidation Projects framework to support the implementation and development of Agricultural Land Consolidation.

The main take-offs of the Agricultural Land Consolidation Projects should assist national and local officials as well as decision-makers involved in Agricultural Land Consolidation to analyze policy and procedural constraints and opportunities to ensure the above-mentioned process as a viable option and to strengthen movement towards eliminating hunger and food shortages and poverty due to the rapidly growing the world's population and coronavirus pandemic.

Currently, to accelerate the progress of Agricultural Land Consolidation and improve the efficiency of farming, it is very important to develop a working digital model of the Agricultural Land Consolidation Projects.

Due to it, the modified Agricultural Land Consolidation Project Logical Framework Matrix (ALCPLFM) has been designed (see Table 12).

The implementation of the Agricultural Land Consolidation Projects begins with an analysis of the relations of land ownership and land use developed in the region taking into account geographical, economic, national, religious, and other conditions.

Thus, it is necessary to determine the owners and beneficiaries of the Agricultural Land Consolidation Project.

It should be emphasized that at present the relations of land ownership in Russian agriculture are largely complex and confusing because, during the reorganization of former state and collective farms, the land shares granted to former collective farmers and workers of state farms were not allocated in kind and demarcated on the ground. In this regard, it is necessary to find the owners of land shares, many of whom have already left the countryside and live-in large cities, to obtain their consent to sell or lease their virtual land shares, which is very difficult, and sometimes impossible.

The final shaping of consolidated agricultural land massive should be carried out gradually, step by step, annually combining similar agricultural land plots in terms of geodetic and land use planning characteristics, location, and property rights.

Next, it is necessary to form optimal agricultural land allotments, determine their geographical coordinates, and demarcate their boundaries.

Implementing this task is often complicated and requires considerable time, ultimately determining the duration of the Agricultural Land Consolidation Project's Life Cycle (Figure 4).

In turn, the duration of the Agricultural Land Consolidation Project's Life Cycle determines the discount rate, which is used in the calculation of cost, benefits, and determination of indicators of financial and economic efficiency of the Agricultural Land Consolidation Projects.

The costs of a land consolidation project in agriculture are determined much more easily than the benefits of its implementation and include the following components:
- costs associated with the definition and clarification of land ownership and land use rights in the implementation of agricultural land consolidation;

- costs of carrying out geodetic works;

- costs of land use planning works; costs of state registration of land ownership rights.

Table 12. Agricultural Land Consolidation Project Logical Framework Matrix

\begin{tabular}{|c|c|c|c|}
\hline Content & $\begin{array}{l}\text { Verified } \\
\text { Indicators }\end{array}$ & $\begin{array}{l}\text { Narrative } \\
\text { Summary }\end{array}$ & Assumptions \\
\hline Super goal & $\begin{array}{l}\text { Increase the } \\
\text { efficiency of } \\
\text { agricultural } \\
\text { production, } \\
\text { eliminate } \\
\text { hunger and } \\
\text { poverty, } \\
\text { mitigate the } \\
\text { negative } \\
\text { impact of the } \\
\text { coronavirus } \\
\text { pandemic }\end{array}$ & $\begin{array}{l}\text { Increasing } \\
\text { financial } \\
\text { and } \\
\text { economic } \\
\text { efficiency of } \\
\text { agricultural } \\
\text { production }\end{array}$ & $\begin{array}{l}\text { Growth of } \\
\text { land rent and } \\
\text { price of } \\
\text { agricultural } \\
\text { land }\end{array}$ \\
\hline $\begin{array}{l}\text { Specific } \\
\text { Objectives }\end{array}$ & $\begin{array}{l}\text { Increase, } \\
\text { optimization of } \\
\text { the size and } \\
\text { configuration } \\
\text { of land parcels, } \\
\text { elimination of } \\
\text { mosaic land } \\
\text { ownership }\end{array}$ & $\begin{array}{l}\text { Improving } \\
\text { the } \\
\text { efficiency of } \\
\text { the use of } \\
\text { agricultural } \\
\text { machinery }\end{array}$ & $\begin{array}{l}\text { Growth of } \\
\text { agricultural } \\
\text { production }\end{array}$ \\
\hline Activities & $\begin{array}{l}\text { List of geodetic } \\
\text { and land use } \\
\text { planning work } \\
\text { in physical } \\
\text { terms, } \\
\text { application } \\
\text { Sattelite } \\
\text { Imagery, and } \\
\text { UAV }\end{array}$ & $\begin{array}{l}\text { The volume } \\
\text { of geodetic } \\
\text { and land } \\
\text { use } \\
\text { planning } \\
\text { work in } \\
\text { physical } \\
\text { terms }\end{array}$ & $\begin{array}{l}\text { Owners and } \\
\text { beneficiaries } \\
\text { of the project }\end{array}$ \\
\hline Investment & $\begin{array}{lr}\text { Financing of } \\
\text { land } \\
\text { planning work }\end{array}$ & $\begin{array}{l}\text { The } \\
\text { investment } \\
\text { required } \\
\text { for the } \\
\text { implement } \\
\text { ation of } \\
\text { land use } \\
\text { planning } \\
\text { work }\end{array}$ & $\begin{array}{l}\text { Attracting } \\
\text { outside } \\
\text { investors to } \\
\text { finance the } \\
\text { project }\end{array}$ \\
\hline $\begin{array}{l}\text { Investment } \\
\text { sources }\end{array}$ & $\begin{array}{l}\text { Ensuring } \\
\text { targeted } \\
\text { investment } \\
\text { financing }\end{array}$ & $\begin{array}{l}\text { Lending is } \\
\text { required to } \\
\text { provide } \\
\text { targeted } \\
\text { financing } \\
\text { for the } \\
\text { Agricultura } \\
\text { l Land } \\
\text { Consolidati } \\
\text { on Project. } \\
\text { Commercia } \\
\text { l bank's } \\
\text { interest } \\
\text { rate policy. } \\
\text { Issuing } \\
\text { corporate } \\
\text { bonds, } \\
\text { MBS, CMO }\end{array}$ & $\begin{array}{l}\text { The Central } \\
\text { Bank's policy } \\
\text { and } \\
\text { refinishing } \\
\text { rate. } \\
\text { Market } \\
\text { interest rate } \\
\text { Inflation rate }\end{array}$ \\
\hline
\end{tabular}


At the same time, in the cost structure, the largest share is occupied by the costs of conducting geodetic and land use planning works.

To reduce and optimize the financial and time costs of the Agricultural Land Consolidation Projects, Gantt charts, and network graphs to monitor the progress of its implementation should be developed.

A significant reduction in the cost of implementing Agricultural Land Consolidation Projects is also provided by the use of satellite imagery and UAVs during geodetic and land use planning works.

The benefits of the Agricultural Land Consolidation project are characterized by an increase in the value of agricultural products produced and sold and a reduction in transaction costs resulting from the consolidation of agricultural land.

At the same time, financial benefits are calculated in current or accounting prices, and economic benefits - in "shadow" or replacement prices.

Based on the financial and economic assessment of the costs and benefits of the Agricultural Land Consolidation Projects the following indicators of its financial and economic efficiency are determined: NPV (Net Present Value); PI (Profitability Index); IRR (Internal Rate of Return); PP (Payback Period); DPP (Discounted Payback Period); ROI (Return on Investment); AAR (Average Accounting Return); ROA (Return on Assets); ROE (Return on Equity); Other financial coefficients.

Agricultural Land Consolidation Projects Risk Analysis focuses on the application of the Scenario Analysis, Sensitivity Analysis, and the Monte Carlo or simulation methodology to the consolidation of agricultural land.

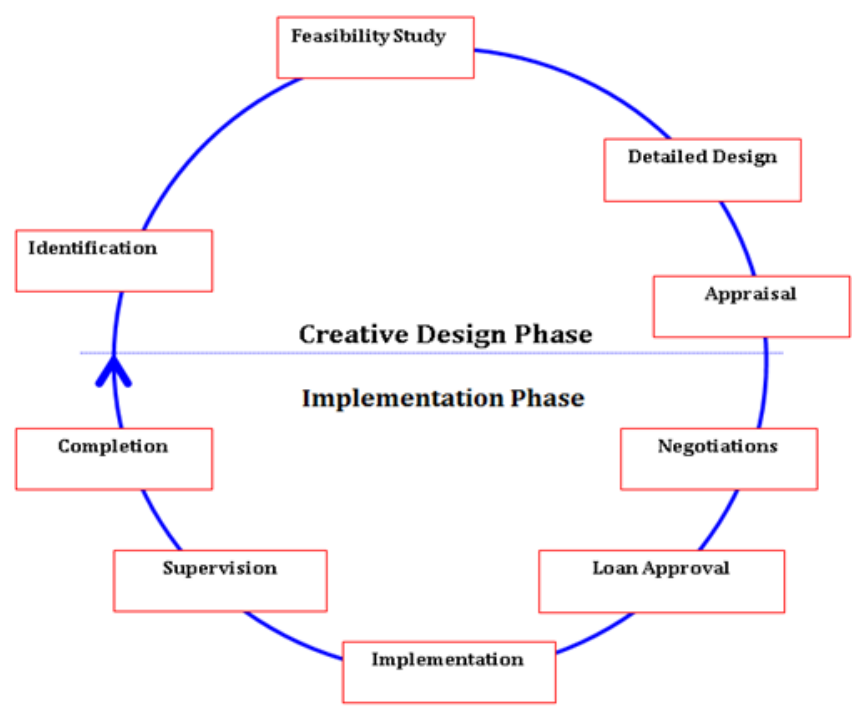

Figure 4. Agricultural Land Consolidation Project's Life Cycle

\section{DISCUSSION}

In the above-mentioned land cadaster valuation guidelines, there are several controversial points concerning the implementation of the state cadastral assessment of agricultural land.
In the methodology, it is practically proposed to evaluate the natural fertility of soils, i.e., the fertility of the land given from "nature".

At the same time, however, it does not take into account the fact that the economic, i.e. the actual fertility of agricultural land allotments currently available is an inseparable synthesis of natural and artificial, i.e. humanmade, fertility.

The artificial fertility of the soil acts as an added value concerning the natural soil's fertility, which has no value, and changes in connection with the development of the productive forces of society.

In this regard, in our opinion, there are problems with the use of the so-called "standard yield" indicator for cadastral assessment, since it characterizes not only the quality of the soil but also the influence of factors of intensification of agricultural production on land productivity.

This problem was faced by Vasily Dokuchaev and Nikolay Annensky when assessing land in the Nizhny Novgorod province in 1882-1886.

They are forced to refine the soil's natural history survey significantly and introduced an indicator of the so-called "normal yield of grains" for land assessment.

To eliminate the influence of the intensification factors, Vasily Dokuchaev and Nikolay Annensky used the method of statistical combinational groupings. However, they failed to completely solve this problem (even with a relatively low level of intensification at that time) when assessing land in the Nizhny Novgorod province.

The above-mentioned problem was also not solved in the methodology of economic land valuation prepared by Sergey Cheremushkin in the early 60s of the last century and the temporary All-Union Land Valuation Methodology developed by the former State Institute of Land Resources (GIZR) in 1976. However, it was proposed to use two methods: selecting typical farms and correlation and regression analysis.

As a result, the fertility of the land was evaluated together with the economic factors associated with the intensification of agricultural production.

Besides, the guidelines mentioned earlier still contain problems related to the validity of the calculation of cadastral valuation indicators, such as the standard yield of crops, gross income, and land rent.

The disadvantage of the method is that it does not give any algorithm for determining the standard yield of crops.

Also: "Gross income is calculated for a unit of land area as the product of the standard yield of an agricultural crop on its market price".

However, this indicator should not be considered as gross income, but as the value of gross output for a particular crop when evaluated at market prices, which is also not sufficiently justified, since not all agricultural products can be sold on the market.

Moreover, "The determination of the cadastral value of agricultural land suitable for arable land is carried out by the method of capitalization of land rent, which is calculated as the difference between gross income and the cost of cultivating and harvesting agricultural products". 
However, this does not consider the fact that gross income itself represents the difference between the value of gross agricultural output and material costs. In the interpretation of the methodology, it is not the land rent that is capitalized, but the profit, which acts as the difference between the revenue and the cost of products sold.

Due to it, a new, innovative agricultural land valuation methodology based on market economy principles should be developed and introduced in this connection.

\section{CONCLUSION}

The main takeaway of the paper is that necessary to implement the legal, organizational, technical, institutional, financial, economic, environmental, and social measures to support the development of Agricultural Land Consolidation based on the Agricultural Land Market in Russia.

In that sense, it's very important to revise and improve Agricultural Land Consolidation and Agricultural Land Market legislation.

The other takeaway of the paper is to implement the institutional framework for the development of Agricultural Land Consolidation and Agricultural Land Market.

It's also necessary to introduce the Agricultural Land Auctions, "call", "put", and "forward" contracts for agricultural land to stimulate the development of the Agricultural Land Market and Agricultural Land Consolidation in Russia.

There is a need to design and introduce education programs related to Agricultural Land Consolidation and Agricultural Land Market Development.

It's also imperative to start a PR campaign to strengthen people's ability to understand the role and importance of Agricultural Land Consolidation Agricultural Land Market Development.

A new, innovative agricultural land cadastral valuation methodology based on market economy principles should be developed and introduced.

One more takeaway of the paper is the necessity to launch pilot projects focused on Agricultural Land Consolidation and Agricultural Land Market Development to make a demonstration effect.

It is also crucial to apply the Project Analysis Principles Approach to design and implement Agricultural Land Consolidation Projects.

Furthermore, last but not least, a need to collect, scrutinize, disseminate, and replicate positive Agricultural Land Consolidation and Agricultural Land Market Development experience (Sagaydak and Sagaydak 2021).

\section{ACKNOWLEDGMENT}

The authors express their deep appreciation and gratitude to the editorial board for the opportunity to submit their scientific article on the problems of agricultural land consolidation for publication in this journal.

\section{Author contributions}

Alexander Sagaydak: Conceptualization, Methodology, Writing-Original draft preparation, Writing-Reviewing and Editing. Anna Sagaydak: Data curation, Visualization, Investigation.

\section{Conflicts of interest}

The authors declare no conflicts of interest.

\section{REFERENCES}

Backman, Mats (2010) Cost-Benefit Analysis of Land Consolidation in Sweden from View Point of Society and Landowner. XXIV Congress FIG "Facing Challenges-Building the Capacity", Sydney, Australia, 11-16 April 2010

Backman, Mats (2016) Cost-Benefit Analysis of Land Consolidation in Sweden from View Point of Society and Landowner. Proceedings of Symposium on Land Consolidation and Land Readjustment for Sustainable Development, 9-11 November 2016, Apeldoorn, Netherlands

Backman, Mats (2016). Basic Requirements for Successful Land Consolidation. Proceedings of Symposium on Land Consolidation and Land Readjustment for Sustainable Development, 9-11 November 2016, Apeldoorn, Netherlands

Becker, Michael, Halimi Kaplan (2019) Land Consolidation as a multi-purpose Instrument exploring Opportunities and addressing Challenges in Kosovo. Annual World Bank Conference on Land and Poverty, Washington DC, March 25-29, 2019

Biarel B, Hazell P, Place F \& Quiggin J (1992). The economics of Farm fragmentation: evidence from Ghana and Rwanda, World Bank Economic Review, 6, 233-254

Konttinen K (2016). The effectivity of Land Consolidation in Finland. Proceedings of Symposium on Land Consolidation and Land Readjustment for Sustainable Development, 9-11 November 2016, Apeldoorn, Netherlands

Krigsholm P, Keskitalo J, Riekkinen K, Niironen J \& Kolis Karin (2016). Evaluating Regional Impact of Land Consolidation Projects. Proceedings of Symposium on Land Consolidation and Land Readjustment for Sustainable Development, 9-11 November 2016, Apeldoorn, Netherlands

Legal guide on land consolidation: Based on regulatory practices in Europe. FAO Legal Guide, No. 3. Rome, FAO (2020)

Meijer G \& Emmens N (2016). Financial arrangements in Land Consolidation. Proceedings of Symposium on Land Consolidation and Land Readjustment for Sustainable Development, 9-11 November 2016, Apeldoorn, Netherlands

Rating of the largest owners of agricultural land in Russia in May 2020 (2020);

Regional Report on the Status and Use of Lands in Kalmykia in 2019, Kalmykiareestr (2020). 
Sagaydak A, Sagaydak A (2016). Problems of forming the auction price of land in agriculture. Zemleustroistvo, kadastr i monitoring zemel, 7, 38-47

Sagaydak A, Sagaydak A (2021). Economics and organization of agricultural production, KnoRus Publishing House. ISBN 978-5-406-07159-5.

Satana S, Ceylan A R, Sert A (2017). The Turkish Experience in Consolidation of Irrigated Land: Productivity and Efficiency Implications. Annual World Bank Conference on Land and Poverty, Washington DC, March 20-24, 2017

Sky P K (2015) Land consolidation in Norway in an international perspective. Spanish Journal of Rural Development, Vol. VI (1-2), 81-90

Sulonen K \& Kotilainen, S (2016). Lessor's Status in Land Consolidation in Finland. Nordic Journal of Surveying and Real Estate Research,1-11,18-36
The State (National) Report on the Status and Use of Lands in Russia in 2019, Rosreestr (2020)

Thomas J (2006) Attempt on Systematization of Land Consolidation Approaches in Europe. Zeitschrift für Geodäsie, Geoinformation und Land management, 3, 156-161

Van den Noort P C (1987). Land consolidation in the Netherlands. Land Use Policy, 4 (1), January 1987, 1113. Elsevier Ltd.

Voluntary Guidelines on the Responsible Governance of Tenure of Land, Fisheries and Forests in the Context of National Food Security (2012), Rome, FAO 